Taras Shevchenko National University of Kyiv, Institute of High Technologies

(4g, Prosp. Academician Glushkov, Kyiv 03022, Ukraine; e-mail: alk@mail.kiev.ua)

\title{
AMORPHOUS SUBMICRON LAYER IN DEPLETION REGION: NEW APPROACH TO INCREASE THE SILICON SOLAR CELL EFFICIENCY
}

\begin{abstract}
The insertion of a thin amorphized layer $(A L)$ in the space charge region of a silicon solar cell is proposed as a way to improve the conversion efficiency due to the impurity photovoltaic effect. Previously, this approach had been applied to a cell with a layer inserted in the emitter by the ion implantation. The insertion of such layer in the space charge region is founded to be preferable, because a better control over the recombination (via energy levels in the band gap and local states of interfaces) can be achieved. The parameters of a modified device are investigated by the numerical simulation, and it is concluded that the layer parameters have a crucial influence on the cell conversion efficiency. Based on our simulation results, the optimal $A L$ and the height of barriers are determined. In such a case, the short circuit current density is improved due to the absorption of photons with energy less than a silicon band gap of $1.12 \mathrm{eV}$ in $A L$, whereas the open circuit voltage and fill factor remain unchanged. Theoretically, the increase in the efficiency by 1-2\% is achievable. In the non-optimal case, the degradation of a short circuit current and the fill factor eliminate the positive effect of an additional photogeneration in $A L$.
\end{abstract}

Keywords: amorphized layer, space charge region, $n^{+}-p$ silicon solar cell.

\section{Introduction}

The semiconductor structures based on crystalline silicon occupy the principal part of the world market despite the intense thin-film technologies development [1]. The asymmetric $n^{+}-p$ junction is known as one of the basic semiconductor structures for silicon photovoltaic. Over the last decades, the efficiency of such devices has been close to the theoretical limit $(\sim 31 \%)$ due to a variety of technological and structural solutions, which allow one to minimize the recombination and the contact and reflective losses. According to research papers, the record efficiency of laboratory cells is $24 \%$, while the standard industrial devices demonstrate $17-20 \%[2,3]$.

At present, many authors develop promising methods for increasing the efficiency, by using antireflective nanostructured coatings [4].

To make the silicon photovoltaic competitive with the traditional energy sources and reach the efficiency beyond this limit, new approaches should be taken into account [2]. The fundamental reason restricting a

(c) A.V. KOZINETZ, V.A. SKRYSHEVSKY, 2018 future growth of the conversion efficiency is the inability to use photons with energy less than $1.12 \mathrm{eV}$ (silicon band gap) for the photovoltaic conversion (fraction of such photon is nearly $40 \%$ for AM 1.5 spectrum) [5]. One of the possible strategies to use such photons is the impurity photovoltaic effect (other way is the utilization of $\mathrm{Si}-\mathrm{Ge}$ quantum wells or $\mathrm{Si}_{x} \mathrm{Ge}_{1-x}$ alloys). It assumes the insertion of an impurity with deep energy levels (like In, Er, S, Te) in crystalline silicon for the infrared photogeneration via the "two step" process. Such modification of crystalline silicon can be produced by the ion implantation technique with a subsequent annealing. It can be distinguished from the "extended" modification [6-8], where deep levels are inserted throughout the bulk region, or the "local" one, where deep levels are inserted in a restricted part, by forming the so-called "amorphizied layer" of 100-150 nm in thickness buried in an emitter [9-12]. The theoretical and experimental studies of the impurity photovoltaic effect in silicon cells have been fulfilled over the last fifty years, but, unfortunately, there is no considerable progress till now. So, for example, an increase of the short circuit current 
density up to several percent $\left(1-6 \mathrm{~mA} / \mathrm{cm}^{2}\right)$ is achievable for "extended" modifications, but the open circuit voltage can be slightly reduced, because the inserted impurity levels act as recombination centers as well. The main problems for both versions of this approach are the weak infrared absorption, instability of optical dopants, and additional recombination via inserted deep levels. As follows from the analysis in [13-19], the principal directions of research in this field are the optical dopant screening (including a deep/shallow dopant system or dopants, which produce more than one deep level $[16,17])$ and the structural design in a modified device (such as $n-p$ $p^{+}$cell with an optical dopant inserted in the $p$-base only), whereas the $p^{+}$-layer provides a better open circuit voltage control $[18,19]$. It should be noted that the light trapping is absolutely required in all cases.

There are some experimental and theoretical evidences that the infrared photo generation occurs more efficiently, when non mid-gap deep levels are inserted in the cell region, where the concentration of carriers is typically low, i.e. in the space charge region of a $n-p$ junction or $i$-layer of the $p-i-n$ structure [20-23]. In the present work, we consider the asymmetric $n^{+}-p$ junction with a thin $\mathrm{AL}$ inserted inside the space charge region (Fig. 1). The layer thickness was chosen less than the diffusion length, and it is expected that most carriers generated by infrared light pass to the space charge region without recombination. Thus, deu to the strong electric field inside AL and the optimal diffusion length, almost ideal conditions for the carrier collection are realized. However, it should be noted that the "local" amorphization of silicon can lead to increasing the energy band gap up to $1.6-1.8 \mathrm{eV}$ and, according to the Anderson model, the appearance of potential barriers [7]. Obviously, additional barriers in the space charge region change the current flow in an initial cell significantly. The positive effect, due to a restriction of the electron injection from the $n^{+}$-emitter, can be accompanied by additional recombination losses associated with the accumulation of carriers, especially when the forward bias is applied. That is why, even if the efficient infrared photogeneration in AL occurs, the influence of a modification on the initial cell performance can be negative in some cases. This possibility has not been analyzed in research papers previously. In addition, the param-

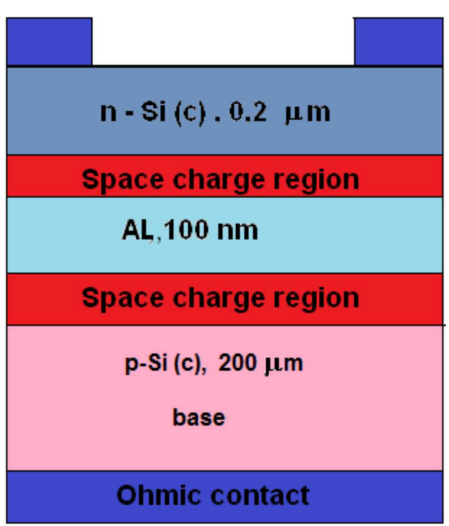

Fig. 1. Schematics of a silicon solar cell based on the asymmetric $n^{+}-p$ junction with a wide-band-gap amorphized layer in the space charge region. The impurity photovoltaic effect occurs via deep energy levels inside this layer

eters of the implanted impurity profile and, hence, the parameters of AL can be varied over a wide range depending on the implantation/annealing or epitaxial growth conditions [24]. Based on the numerical simulation results, we determine the optimal parameters (position and height of barriers), when the positive effect of infrared generation allows one to increase the efficiency. In principle, the obtained results are applicable to any asymmetric $n^{+}-p$ junction with a wide band gap semiconductor layer, in which the additional infrared photogeneration via deep defect levels occurs.

\section{Numerical Simulation Method and Device Parameters}

Our investigation primarily focuses on how the complex band structure of a modified junction affects the cell performance. That is why the 1-D simulation program AFORS-het can be chosen. The version 2.2 solves the system of one-dimensional equations (Poisson's equation and the transport equation for electrons and holes) with the help of the finite differences method. It allows us to determine the band structure, spatial distribution of non-equilibrium carriers, current density-voltage curves, etc. In such a way, some principal aspects of the device operation can be clarified [25].

The reference cell consists from two regions: $n^{+}-\mathrm{Si}$ and $p$-Si. We choose parameters corresponding to a "mediocre" quality device: the doping concentration of the $n^{+}$-Si region is $N_{D}=10^{18} \mathrm{~cm}^{-3}$, thickness is 
$0.2 \mu \mathrm{m}$, hole diffusion length is $0.8 \mu \mathrm{m}$; the concentration of acceptors in $p$-Si is $N_{A}=10^{16} \mathrm{~cm}^{-3}$, thickness is $200 \mu \mathrm{m}$, electron diffusion length is $130 \mu \mathrm{m}$, and front surface recombination velocity is equal $10^{3} \mathrm{~cm} / \mathrm{s}$. For these doping levels, the built-in potential is $\psi_{0}=0.8 \mathrm{eV}$, and the space charge region is nearly completely located in the $p$-base. Its width at the zero bias is $L=0.5 \mu \mathrm{m}$. The cell parameters at standard AM 1.5, $0.1 \mathrm{~W} / \mathrm{cm}^{2}$ illumination are: the short circuit current density $J_{L}=26.5 \mathrm{~mA} / \mathrm{cm}^{2}$, open circuit voltage $V_{o c}=690 \mathrm{mV}$, saturation current density $J_{o}=4 \times 10^{-11} \mathrm{~mA} / \mathrm{cm}^{2}$, fill factor $F F=83 \%$, which results in the conversion efficiency $\eta=15.4 \%$. The operation of a reference cell can be described by the conventional equation

$J(V)=J_{L}-J_{o}\left(\exp \left(\frac{e V}{k T}\right)-1\right)$,

where $k$ is the Boltzman constant, $e$ is the electron charge, and $V$ is the applied bias.

The $p$-base of a modified device included three regions: $\# 1-p-\mathrm{Si}, \# 2-\mathrm{AL}$, and \#3-p-Si. The thickness of region $\# 1$ was varied in such a way that $\mathrm{AL}$ was always in the space charge region in the equilibrium state. So, the total base thickness was always kept equal to $200 \mu \mathrm{m}$. The AL was described by the standard $\alpha$-Si model. To obtain the different heights of barriers, the band gap and electron affinity were artificially varied. With the free carrier concentration in $\mathrm{AL}$ less than $10^{15}-10^{16} \mathrm{~cm}^{-3}$, the layer is fully depleted, and the appropriate band bending near interfaces (i.e. when the carriers photogenerated in AL flow to the silicon space charge region without storage and recombination) can be obtained. The origin of localized states in the band gap was assumed to be a result of band tails and dangling bonds. Thus, the

Input parameters of $\mathrm{AL}$ used in the simulation

\begin{tabular}{|l|c|}
\hline \multicolumn{1}{|c|}{ Parameters } & AL \\
\hline Layer thickness $(\mathrm{nm})$ & 100 \\
Dielectric constant & 11.9 \\
Electron affinity $(\mathrm{eV})$ & varied $(3.9-4.3)$ \\
Band gap (eV) & varied $(1.12-1.8)$ \\
Effective conduction band density $\left(\mathrm{cm}^{-3}\right)$ & $1 \times 10^{20}$ \\
Effective valence band density $\left(\mathrm{cm}^{-3}\right)$ & $1 \times 10^{20}$ \\
Electron mobility $\left(\mathrm{cm}^{2} \mathrm{~V}^{-1} \mathrm{~s}^{-1}\right)$ & 5 \\
Hole mobility $\left(\mathrm{cm}^{2} \mathrm{~V}^{-1} \mathrm{~s}^{-1}\right)$ & 1 \\
\hline
\end{tabular}

diffusion length in AL was $0.2-0.5 \mu \mathrm{m}$, which is typical of amorphous silicon with moderate conductivity. The layer thickness was kept equal to $100 \mathrm{~nm}$. All other parameters are indicated in Table.

In our consideration, the total photocurrent density includes two components. One component, $\left(J_{L}^{m}\right)$, is associated with the absorption of photons with energy more than the silicon band gap $(1.12 \mathrm{eV})$. It was calculated with the simulation program AFORShet. The other component, additional photocurrent $\left(J_{L}^{\mathrm{AL}}\right)$, is associated exclusively with the absorption of photons, whose energy is less than the silicon band gap. As the layer thickness was chosen less than the diffusion length, it was evaluated with a simplified analytical expression

$J_{L}^{\mathrm{AL}}=(1-R) e \int_{\lambda_{1}}^{\lambda_{2}} N(\lambda)\left(1-e^{-\alpha_{\mathrm{AL}} d_{\mathrm{AL}}}\right) d \lambda$

where $e$ is the electron charge, $\alpha_{\mathrm{AL}}$ is the absorption coefficient in the infrared range, $R$ is the reflection coefficient at the interface Si-AL, $N(\lambda)$ is the incident photon flux, and $d_{\mathrm{AL}}$ is the layer thickness. Alternatively (and probably with higher accuracy), $J_{L}^{\mathrm{AL}}$ can be calculated, according to a modified Shockley-Read-Hall model that involves the generation-recombination process through inserted deep levels $[16,18]$.

In this way, the operation of a solar cell with the inserted layer is described by the equation [26, 27]

$J^{m}(V)=J_{L}^{m}+J_{L}^{\mathrm{AL}}-J_{o}^{m}\left(\exp \left(\frac{e V}{n k T}\right)-1\right)$

where $J_{o}^{m}$ is the saturation current, and $n$ is the ideality factor. According to the analytical approach developed in [28], the values of $J_{L}^{m}, J_{o}^{m}$, and $n$ can depend on the applied bias and parameters of the inserted layer.

Figure 2 presents the band diagrams of a modified device without external bias $(a)$ and with direct voltage, which is slightly less than the open circuit voltage (b). Parameters of photovoltaic conversion were calculated for a modified device for different layer positions inside the space charge region $x_{\mathrm{AL}}$ and different heights of potential barriers $\varphi_{c}$ and $\varphi_{v}$. The radiation source AM 1.5 with a power density of $0.1 \mathrm{~W} / \mathrm{cm}^{2}$ was used in our simulation.

ISSN 2071-0194. Ukr. J. Phys. 2018. Vol. 63, No. 1 


\section{Results and Discussion}

\subsection{Influence of $A L$ parameters on the dark current-voltage}

In this section, we will analyze the dark $J-V$ curves of a modified device. Figure 3 illustrates the curves calculated for layers with different barriers in the conduction band $\left(\varphi_{c}\right)$ inserted at the plane $x_{\mathrm{AL}}=0.1 \mathrm{~L}$. As can be seen, an increase of $\left(\varphi_{c}\right)$ leads to a decrease of the dark current. The shapes of these curves look like the reference curve shape, if the inserted barriers are relatively small $(0.2-0.3 \mathrm{eV})$. However, the effect of the modification becomes significant, if the barrier height is higher than $0.35 \mathrm{eV}$. The deceleration of the current growth can be formally fitted by a one-exponential model with the ideality factor

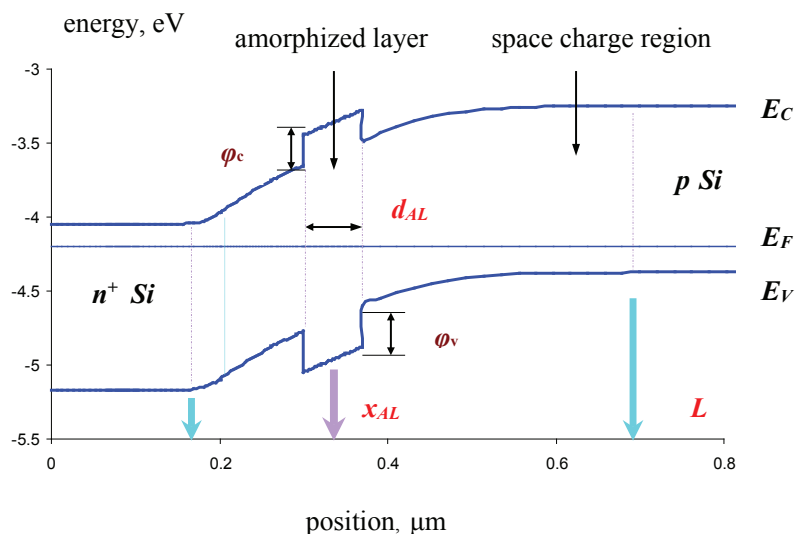

$a$

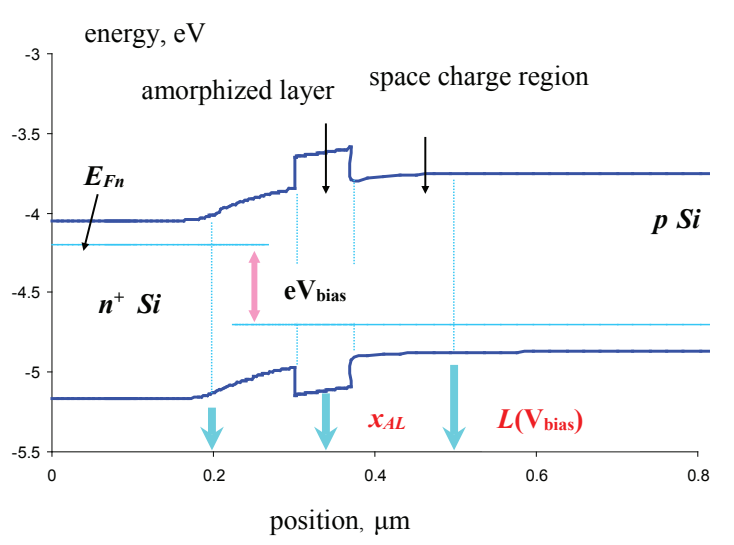

$b$

Fig. 2. Calculated band diagram of a modified cell ( $a$ ) without external bias and with a direct bias of $0.6 \mathrm{~V}(b)$ that is less than the open circuit voltage of a reference cell $n>1$ in these cases. Figure 4, in turn, illustrates the $J-V$ curves calculated for a layer inserted at different positions in the space charge region $(0.1,0.2$, $0.35,0.4$, and $0.5 \mathrm{~L})$, and $\varphi_{c}$ is fixed to $0.4 \mathrm{eV}$. As the space charge region width decreases with the direct bias as $L(V)=L\left(1-e V / \psi_{0}\right)^{1 / 2}$, the layer position was chosen in such a way that it remains inside the space charge region. If $\mathrm{AL}$ is located near

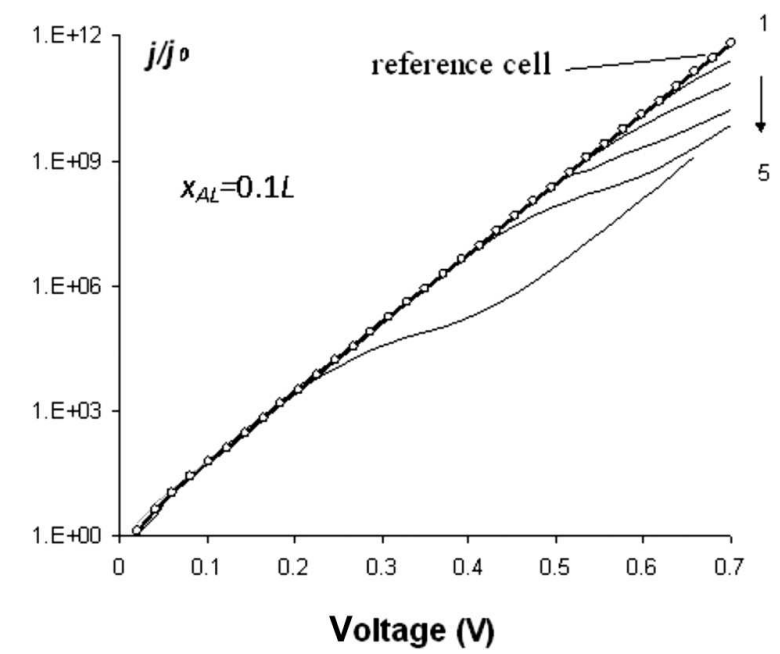

Fig. 3. Calculated dark current-voltage curves of a modified cell for $x_{A L}=0.1 L$ and different potential barriers $\varphi_{c}=0.2$ (1), 0.3 (2), 0.4 (3), 0.45 (4), and $0.5 \mathrm{eV}(5)$

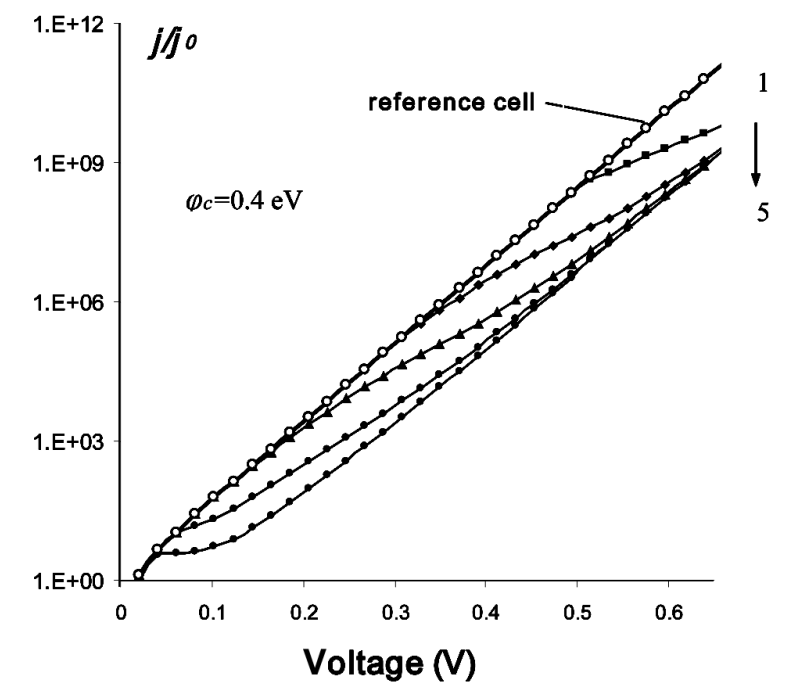

Fig. 4. Calculated dark current-voltage curves of a modified cell for different positions of the amorphized layer $x_{\mathrm{AL}}=0.1$ (1), 0.2 (2), 0.35 (3), 0.4 (4), and $0.5 L$ (5); the value of $\varphi_{c}$ is $0.4 \mathrm{eV}$ 


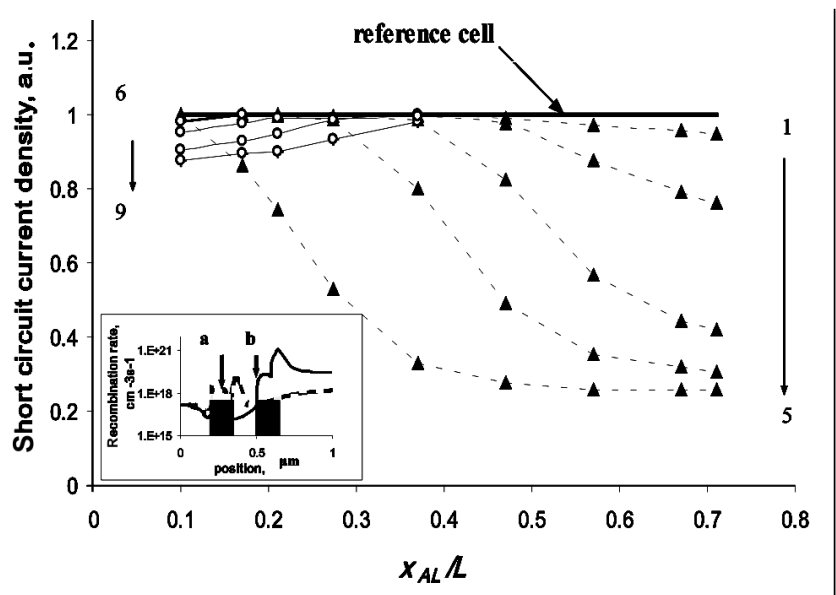

$a$

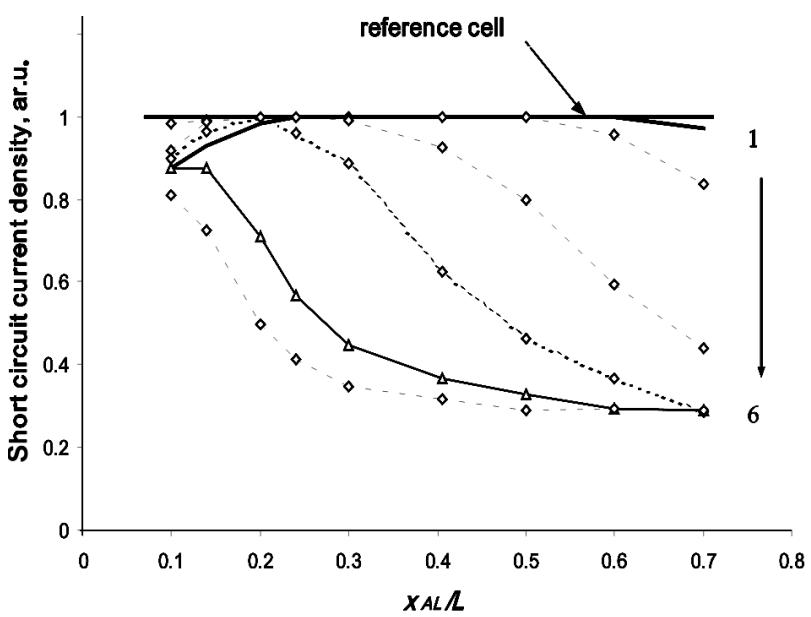

$b$

Fig. 5. Normalized short circuit current density as a function of the layer position calculated for the layer with one barrier: $\varphi_{c}=0.1$ (1), 0.2 (2), $0.3(3), 0.4$ (4), and $0.45 \mathrm{eV}(5), \varphi_{v}=0.2$ $(6), 0.3(7), 0.35(8)$, and $0.4 \mathrm{eV}(9)(a)$; the inset to $(a)$ gives simulated recombination profiles in the space charge region for $x_{\mathrm{AL}}=0.2 L$ (curve $a$ ) and $x_{\mathrm{AL}}=0.6 L$ (curve $\left.b\right)$, and $\varphi_{c}=$ $=0.4 \mathrm{eV}$; Normalized short circuit current density as a function of the layer position calculated for a layer with two barriers: $\varphi_{c}=0.1 \varphi_{v}=0.4$ (1), 0.2, 0.2 (2), 0.3, 0.3 (3), 0.35, 0.35 (4), $0.4,0.4(5)$, and $0.45,0.45 \mathrm{eV}(6)(b)$

the emitter, no difference with the reference curve is observed up to $0.4-0.5 \mathrm{~V}$. If the same layer is located closer to the base region $\left(x_{\mathrm{AL}}>0.2 L\right)$, the additional barrier $\left(\varphi_{c}\right)$ defines the dark current, even when a low external voltage bias is applied. It is worth to note that, in the case $x_{\mathrm{AL}}=0.5 \mathrm{~L}$ (curve 5), the dependence can be fitted by a one-exponential model with $n$ close to 1 and a significantly reduced saturation current $\left(J_{o}^{m} \sim 10^{-13} \mathrm{~mA} / \mathrm{cm}^{2}\right)$. One can say that the dark current can be decreased by orders, by "shifting" the layer toward the base neutral region.

Let us consider, in more details, the physical mechanism of formation of the dark current. When the direct voltage bias $V$ is applied, the electrons from the $n^{+}$-emitter are injected in the $p$-base. The principal reason of decreasing the current should be decreasing the electron concentration $n(L(V))$ at the base neutral region edge (the plane $x=L(V)$, see Fig. 2,b) due to the additional barrier of AL. From our simulation results, it can be concluded that the efficient barrier height (i.e. with respect to the flat conduction band of the $p$-base) defines the dark current. When the direct voltage bias increases, the efficient barrier height increases also, by causing a partial voltage dropping right to the layer. The layer position affects primarily the $J-V$ curve shape at the extent, to which it determines the external voltage bias dropping in the space charge region. In particular, if AL is located near the emitter edge, the electron concentration can be written for the wide range of the direct voltage bias $V$ as $n(L(V)) \sim$ $\sim N_{D} e^{-(\psi 0-e V) / k T}$. But if AL is shifted to the base edge, $n(L(V)) \sim N_{D} e^{-(\psi 0+\varphi c-e V) / k T}$.

As the efficiency of the injection of holes is typically low for the asymmetric $n^{+}-p$ junction, any significant influence of the position and the barrier height in the valence band $\left(\varphi_{v}\right)$ on the dark current in a modified device was not observed in our simulation.

\subsection{Peculiarities of the formation of short circuit current and open circuit voltage in a modified device}

The additional barrier structure should have negative effect on the reference cell performance. The aim of this section is to evaluate the layer parameters allowing onr to minimize this negative effect and to make the infrared photogeneration in AL beneficial.

Figure 5, a presents the normalized short circuit current density (i.e. $J_{L}^{m} / J_{L}$ ) as a function of the layer position. The varied parameter is the potential barrier height. A barrier $\left(\varphi_{c}\right)$ restricts the electron current collected from the $p$-base and from a part of the space charge region, which lies to right from the layer, curve 1-6. Our calculations show that the 
detrimental effect is maximal, when the layer is located near the base region edge, $x_{\mathrm{AL}} \sim 0.7 \mathrm{~L}$. The electros flow from the $p$-base is found to be nearly completely blocked for $x_{\mathrm{AL}} \sim 0.7 L, \varphi_{c} \sim 0.4 \mathrm{eV}$, curves 5,6 . If the layer is shifted to the emitter edge, the efficient barrier is decreased that leads to a gradual increase of the short circuit current. The electrons photogenerated in the $p$-base reach the space charge region edge due to the concentration gradient $d n / d x$, by the diffusion. Then they are drawn into the space charge region by the electric field. The electrons with energy over the potential barrier height pass to the $n^{+}$-emitter. The electrons, whose energy is insufficient to overcome the barrier, are accumulated near the right interface of AL stretched by the electric field of the space charge region. Normally, the accumulation can lead to an enhancement of the recombination. The simulated recombination profiles in the space charge region for $x_{\mathrm{AL}}=0.2 L$ and $x_{\mathrm{AL}}=0.6 \mathrm{~L}$ for $\varphi_{c}=0.4 \mathrm{eV}$ are depicted in the inset to Fig. 5, a. It can be concluded that if $\mathrm{AL}$ is located closer to the base $\left(x_{\mathrm{AL}}=0.6 L\right)$, the electric field is weak (as $|d \psi / d x|=\left|d\left(\psi_{0}(1-x / L)^{2}\right) / d x\right|=$ $\left.=2 \psi_{0}(1-x / L) / L\right)$ ), and the probability of the carrier recombination increases. When $\mathrm{AL}$ is located closer to the emitter $\left(x_{\mathrm{AL}}=0.2 L\right)$, the electric field near the interface is stronger, and the recombination rate is lower. This means that the concentration of accumulated carriers to increase the diffusion can be reached more easily.

Similarly, the barrier $\varphi_{v}$ restricts the current of holes collected from the $n^{+}$-emitter and from a part of the space charge region which lies left to the layer. The physical mechanism of short circuit current formation is qualitatively similar, as described above. When the layer is located near the emitter $\left(x_{\mathrm{AL}}=0.1 L\right)$, the detrimental effect is maximal, but when the layer is shifted to the base edge, the efficient potential barrier height for holes decreases, and the short circuit current increses, curves $6-9$. The flow of holes from the $n$-emitter is found to be blocked for $x_{\mathrm{AL}}=0.1 L, \varphi_{c} \sim 0.4 \mathrm{eV}$, curves 8 , 9. If the layer forms two potential barriers $\varphi_{c}$ and $\varphi_{v}$, the situation becomes more complex, Fig. $5, b$. The inserted $\mathrm{AL}$ restricts both the transport of holes from the $n^{+}$emitter and the transport of electrons from the $p$ base. As can be seen, the non-monotonic dependence of the short circuit current on the layer position is observed, curves $1-4$. In addition, the maximum dis-

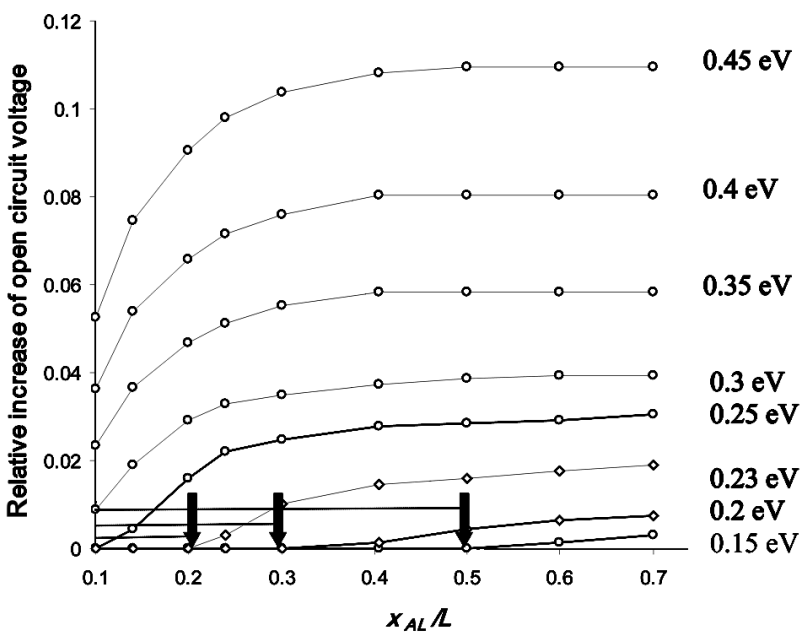

Fig. 6. Relative increase of the open circuit voltage as a function of the layer position calculated for different barrier heights in the conduction band

appears, if $\varphi_{c}=\varphi_{v}>0.4 \mathrm{eV}$, curve 5,6 . The position of the maximum depends on the values of $\left(\varphi_{c}\right)$ and $\left(\varphi_{v}\right)$. One can say that the curves are a result of the combination of oppositely directed trends, as was discussed above.

The open circuit voltage of a modified device was calculated. If AL forms a potential barrier in the valence band only, the saturation current remains nearly unchanged $J_{o}^{m} \sim J_{o}$. Therefore, the variations of the short circuit current and the open circuit voltage are consistent. For the layer with $\varphi_{v} \sim 0.4 \mathrm{eV}$ inserted near the emitter edge, the open circuit voltage decreases by $2 \%$, in accordance with the expression $V=k T / \ln \left(1+J_{L}^{m} / J_{o}\right)$. An improvement of the open circuit voltage is possible, if the layer forms a potential barrier in the conduction band, Fig. 6. This effect is explained by the influence of $\left(\varphi_{c}\right)$ on the dark current, which was discussed in the previous section in detail. To improve the open circuit voltage significantly, the layer with high potential barrier $\varphi_{c}=0.3$ $0.4 \mathrm{eV}$ should be located closer to the base region, and it looks very problematic to avoid the simultaneous degradation of the short circuit current density. It is worth to note that there exists the range of layer positions $\left(x_{\mathrm{AL}}\right)$ allowing to preserve both the open circuit voltage and short circuit current density for $\varphi_{c}<0.2 \mathrm{eV}$ (it is indicated by arrows in Fig. 6).

Another important parameter characterizing the light $J-V$ curves is the fill factor $(F F)$. Its value as a function of the layer position was calculated for a 


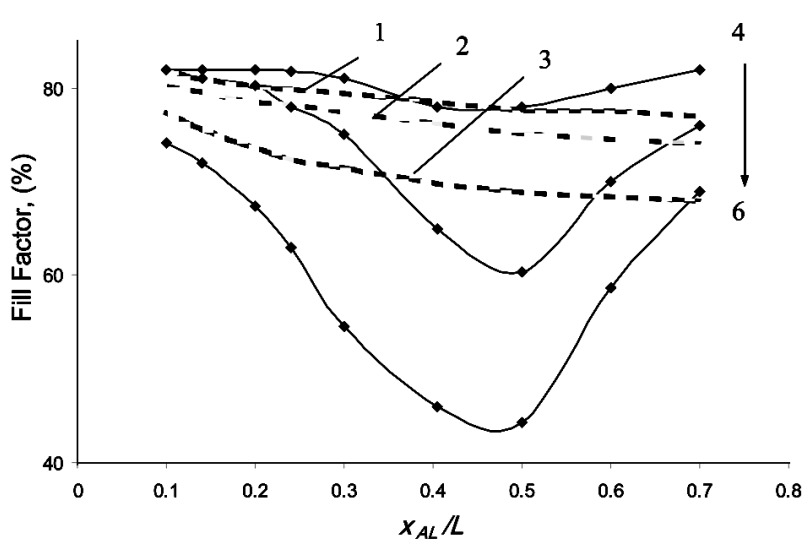

Fig. 7. Fill factor as a function of the layer position calculated for different barrier heights: $\varphi_{c}=0 \varphi_{v}=0.3$ (1), 0.1, 0.4 (2), $0,0.45$ (3), $0.15,0.15(4) ; 0.2,0.2(5)$ and $0.3,0.3(6)$

variety of situations, Fig. 7. Curves 1-3 illustrate the case where the layer forms a potential barrier in the valence band $\varphi_{v}$ only (or when a small barrier in the conduction band with $\varphi_{c}<0.1 \mathrm{eV}$ exists). Since the efficient potential barrier for holes increases with the applied voltage bias, the photocurrent $\left(J_{L}^{m}\right)$ depends on the applied voltage bias as well. To explain the presented dependences, the spatial distribution of the potential within the space charge region should be taken into account (see Fig. 2, $b$; it can be also expressed as $\left.\psi(x) \sim\left(\psi_{0}-e V\right)(1-x / L(V))^{2}\right)$. When the layer is inserted near the emitter edge, the variation of the efficient potential barrier with an applied voltage bias is not significant, and $F F$ reveals a maximal value. However, the variation increases, if the layer is shifted from the emitter to the base edge. Moreover, the concentration of stored holes can be strongly influenced by reduced electric fields that imply additional recombination losses. These reasons, generally, explain a decrease of $F F$, when the layer is shifted to the base edge.

If $\mathrm{AL}$ forms a potential barrier in the conduction band $\left(\varphi_{c}\right)$, details of the dependences becomes quite different, curves $4-\%$. As the electron flow is perturbed, the shape of dark $J-V$ curves influences the fill factor. A significant decrease of $F F$ is observed, when the layer is shifted to the middle of the space charge region. Then, as the layer approaches the base edge, FF increases. On the other hand, the degradation of the fill factor is always observed, when $\left(x_{\mathrm{AL}}\right)$ is fixed, and the potential barrier height increases. This fact, as was mentioned above, can be attributed to ad- ditional recombination losses near the AL interfaces, when the forward bias is applied.

As the short circuit current, the open circuit voltage, and the fill factor define the efficiency of a modified cell, some optimization of layer parameters can be proposed. Summarizing the results presented in Fig. 5-7, one can say that the optimal cases are: 1) when the layer with a potential barrier in the valence band $\varphi_{v}<0.4 \mathrm{eV}$ (the barrier in the conduction band $\left.\varphi_{c} \sim 0.1 \mathrm{eV}\right)$ is located at $x_{\mathrm{AL}} \sim 0.2-0.3 L$ $\left(J_{L}^{m} \sim 26-26.5 \mathrm{~mA} / \mathrm{cm}^{2}, V_{o c}^{m} \sim 690 \mathrm{mV}, F F^{m} \sim 76-\right.$ $80 \%)$; 2) when the layer forms two barriers $\varphi_{c}=\varphi_{v} \sim$ $\sim 0.2 \mathrm{eV}$, it should be located at the plane $0.1 \mathrm{~L}<$ $<x_{\mathrm{AL}}<0.3 L\left(J_{L}^{m} \sim 26.5 \mathrm{~mA} / \mathrm{cm}^{2}, V_{o c}^{m} \sim 690 \mathrm{mV}\right.$, $\left.F F^{m} \sim 77-80 \%\right)$; 3) when the layer forms a potential barrier in the conduction band $\varphi_{c}<0.3 \mathrm{eV}$, it should be located near the emitter edge $\left(J_{L}^{m} \sim\right.$ $\sim 26.5 \mathrm{~mA} / \mathrm{cm}^{2}, V_{o c}^{m} \sim 690-697 \mathrm{mV}, F F^{m} \sim 75-$ $80 \%)$. That all correspond to the band gap $E_{\mathrm{AL}}=$ $=1.5-1.6 \mathrm{eV}$.

\subsection{Effect of additional infrared photogeneration in $A L$ on the modified cell conversion efficiency}

The effect of an additional photogeneration on the efficiency of a modified device will be analyzed in this section. Naturally, the calculation of $\left(J_{L}^{\mathrm{AL}}\right)$ should involve the specific features of an inserted deep impurity. In practice, the origin of deep levels, providing the infrared absorption inside AL, might be quite different: deep donor-like impurity, deep acceptorlike impurity in couple with a shallow donor-like one for the compensation, post-implanted point defects, etc. $[15,17,22]$. In our simulation, for simplicity, the case of post-implanted defects is considered [29, 30]. The experimentally measured absorption coefficient $\alpha_{\mathrm{AL}}$ is about $10^{2}-10^{3} / \mathrm{cm}$ in the wavelength range $1.1 \mu \mathrm{m}<\lambda<2.5 \mu \mathrm{m}$. Let us consider the infrared light trapping scheme that provides at least 100 passes of light through the active region of a modified device. The solar cells with the improved light trapping scheme can be achieved via the application, for example, Bragg mirrors [31-33]. The calculation of the additional photocurrent according to (2) with $R=0$ gives $J_{L}^{\mathrm{AL}} \sim 2.4-5 \mathrm{~mA} / \mathrm{cm}^{2}$.

Figure 8, a illustrates the light $J-V$ curves calculated according to (3) for AM 1.5, $0.1 \mathrm{~W} / \mathrm{cm}^{2}$. The modified layer with $\varphi_{c}=\varphi_{v}=0.2 \mathrm{eV}$ was located in

ISSN 2071-0194. Ukr. J. Phys. 2018. Vol. 63, No. 1 
different positions for comparison. As can be seen, if the layer is at the plane $x_{\mathrm{AL}}=0.2 L$, the conversion efficiency improves up to $17 \%$ due to the short circuit current density improvement $\left(J_{L}^{m} \sim 28.9 \mathrm{~mA} / \mathrm{cm}^{2}\right.$, $\left.V_{o c}^{m} \sim 690 \mathrm{mV}, F F^{m} \sim 82 \%\right)$. In addition, the open circuit voltage and the fill factor remain unchanged. If the same layer is inserted at the plane $x_{\mathrm{AL}}=0.5 \mathrm{~L}$ or $0.6 \mathrm{~L}$, the degradation of the short circuit current density in the initial cell eliminates the effect of additional infrared photogeneration at all. The conversion efficiency declines to $12 \%$, which is even less than the efficiency of a reference cell. Figure $8, b$ illustrates the effect of different potential barrier heights for $x_{\mathrm{AL}}=0.45 \mathrm{~L}$ on the open circuit voltage of a modified device. The efficiency firstly increases to $16.5 \%$ $\left(\varphi_{c} \varphi_{v}=0.15 \mathrm{eV}\right)$, but then drastically declines down to $\sim 6 \%\left(\varphi_{c}=\varphi_{v} \sim 0.25-0.4 \mathrm{eV}\right)$. It should be noted that, when the open circuit voltage increases (due to a restriction of the injection from the emitter), the simultaneous significant degradation of the fill factor takes place. As can be concluded from Fig. 8, the conversion efficiency of ma odified device strongly depends on the layer position and its potential barriers. If AL has optimal parameters, as it was discussed in the previous section, an increase of the conversion efficiency of a modified cell by $1-2 \%$ in absolute value can be expected. In the opposite case, the proposed modification leads even to a degradation of the initial efficiency value.

\subsection{Related experimental results and future development}

The efficiency improvement of an asymmetric $n^{+_{-}}$ $p$ junction by $1.5 \%$ due to the In-ion implantation in the space charge region was experimentally obtained in [20-23]. The additional infrared absorption was shown to improve the short circuit current by $10 \%$, whereas the open circuit voltage, dark current, and $F F$ remain nearly unchanged under the optimal conditions of annealing. The explanation of this effect by a minor damage due to the implantation process can be completed, in our opinion, because the possible band gap increase was not taken into account. Namely, if the amorphization of silicon in the space charge region appears, in spite of that, the positive effect of conversion improvement is possible under certain conditions. Our simulation results allow one to partially clarify and to supplement the explanation of these ex-
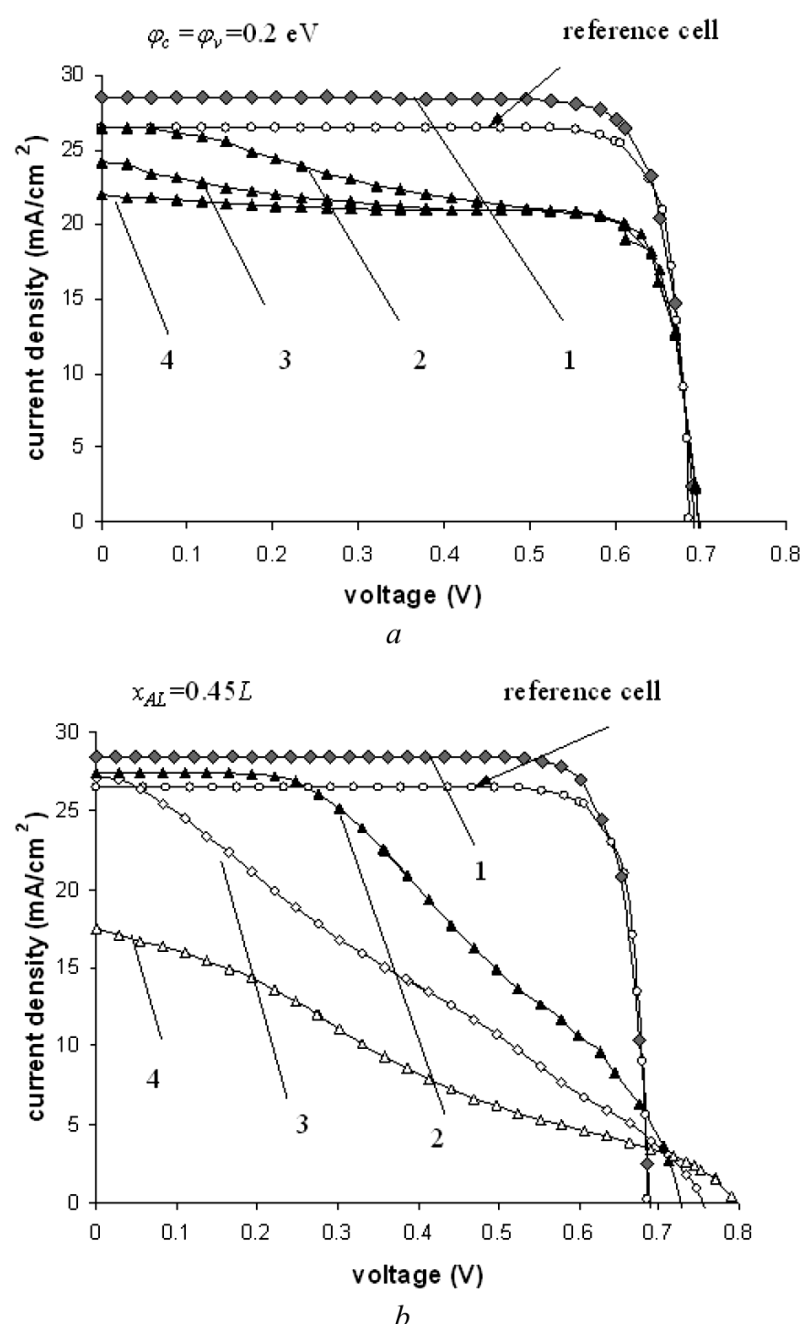

Fig. 8. (a) Calculated light current-voltage curves of a modified cell for different positions of the amorphized layer for $\varphi_{c}=\varphi_{v}=0.2 \mathrm{eV}: x_{\mathrm{AL}}=0.2$ (1), 0.5 (2), 0.6 (3), and $0.65 \mathrm{~L}$ (4). An additional infrared photogeneration in AL is taken into account; light current-voltage curve of a reference cell is also shown. (b) Calculated light current-voltage curves of a modified cell for different barriers for $x_{\mathrm{AL}}=0.45 L: \varphi_{c}=\varphi_{v}=0.15$ (1), 0.25 (2), 0.3 ( 3), and $0.4 \mathrm{eV}$ (4)

perimental results. If the conduction band potential barrier of AL is small, that is the case of the widely used $\alpha$-Si model, the dark-current curve should not be changed for an implanted asymmetric $n^{+}-p$ junction. On the other hand, if AL with a barrier in the valence band in $0.3-0.4 \mathrm{eV}$ is located not in a vicinity of the emitter edge $(0.3 L)$, the degradation of the short circuit current and the open circuit voltage can be minimized. 
The modified solar cells with a buried amorphized layer have been studied by the group of Z. Kuznicki and M. Ley since the 1990s. The point defects, which act as impurity photovoltaic centers, were generated by the P-ion implantation in the $n$-emitter of the asymmetric $n^{+}-p$ junction. The authors reported the $20-\%$ internal quantum efficiency improvement at the near infrared range $\lambda>0.9 \mu \mathrm{m}$ [9]. The TEM analysis clearly indicates that the layer (with a thickness of 100-150 nm at a depth of $100 \mathrm{~nm}$ from the front cell surface) has amorphous structure with two rough interfaces. It was shown that an acceptable fitting of dark $J-V$ curves required the introduction of additional barrier parameters [10]; however, the complete characterization of cells formed under different implantation/annealing conditions was not made. To create an appropriate band bending for the effective minority carrier collection and the interface recombination control, a highly doped AL was utilized [12]. The barrier structure of a modified emitter was treated as the $n-\mathrm{Si}-n^{+}-\mathrm{Si}-n-\mathrm{Si}$ or $n-\mathrm{Si}-n^{+}-\alpha-\mathrm{Si}-n-\mathrm{Si}$ heterojunction, blocking the flow of minority carriers generated between the front surface of the emitter and the upper interface of $\mathrm{AL}[11,12]$. The insertion of a similar structure in the space charge region is believed to be preferable, because a better control of recombination can be achieved, if the built-in potential of the $n-p$ junction drops on the layer volume (that means that the electric field in AL is about $10^{6} \mathrm{~V} / \mathrm{cm}$ ).

Based on the numerical simulation results, a silicon solar cell with improved efficiency can be realized experimentally. On the other hand, several recent studies predict that the "host" material should have wide band gap (like $\beta$-SiC or GaAs) for a more effective application of the impurity photovoltaic effect $[34,35]$. Hypothetically, such wide-gap layer can be inserted in the space charge region of a silicon junction via the epitaxial growth. Our simulation results are believed to help for a careful selection of its parameters.

\section{Conclusions}

The impurity photovoltaic effect, allowing the absorption of photons with energy less than the silicon band gap $(1.12 \mathrm{eV})$ and the additional photogeneration of carriers, is proposed as a way to improve the conversion efficiency of cells based on the $n^{+}-p$ junction. One of the possible approaches to this strategy is the insertion of a thin modified layer in the space charge region by the ion implantation. Instead of an amorphous silicon layer, the layer of another material, like porous silicon [36] and a diamond-like film [37] can be used. However, a partial disordering of the silicon lattice can lead to a local band gap increase and to the potential barrier formation that, in turn, changes the current flows of the initial cell significantly. This situation has been investigated with numerical simulation in the present work. The influence of layer parameters (position, barrier height) on the cell efficiency in view of the additional infrared photogeneration is analyzed in details. An increase of the conversion efficiency by $1-2 \%$ is achievable due to the additional infrared absorption. In this case, the short circuit current density improves, whereas the open circuit voltage and the fill factor remain nearly unchanged. This increase can be achieved, for example, if the layer with barriers in the valence $(<0.4 \mathrm{eV})$ and conduction $(<0.1 \mathrm{eV})$ bands are inserted at the plane corresponding to 0.3 of the space charge region width. It looks very problematic to get a simultaneous improvement of the short circuit current density and the open circuit voltage by choosing the appropriate layer parameters. Our modeling show that an increases in the open circuit voltage by $10-12 \%$ due to a restriction of the injection in the $p$-base is accompanied by a degradation of the short circuit current density. To improve the open circuit voltage, the layer with a high potential barrier height in the conduction band $(0.4 \mathrm{eV})$ should be located closer to the base region that causes the unavoidable recombination losses in the space charge region, especially when the forward voltage bias is applied. It can be concluded that layer parameters has a crucial influence on the initial cell conversion efficiency. To have a future efficiency improvement, layers with high absorption coefficient in the infrared range and with interfaces of good qualities are required. Preliminary experimental data have been discussed.

This work was partially supported by the scientific grant of Taras Shevchenko Natrional University of Kyiv (0111U006258).

1. G.S. Khrypunov, E.P. Chernykh, N.A. Kovtun, E.K. Belonogov. Flexible solar cells based on cadmium sulfide and telluride. Semiconductors 43, 1046 (2009).

2. M.A. Green. The path to $25 \%$ silicon solar cell efficiency: History of silicon cell and evolution. Progress in Photovoltaics 17, 320 (2009).

ISSN 2071-0194. Ukr. J. Phys. 2018. Vol. 63, No. 1 
3. A. Luque. Will we exceed $50 \%$ efficiency in photovoltaics? J. Appl. Phys. 110, 031303 (2011).

4. N.P. Klochko, G.S. Khrypunov, Y.O. Myagchenko, E.E. Melnychuk, V.R. Kopach, K.S. Klepikova, V.M. Lyubov, A.V. Kopach. Electrodeposited zinc oxide arrays with the moth-eye effect. Semiconductors 48, 531 (2014).

5. A.S. Brown, M.A. Green. Impurity photovoltaic effect: Fundamental energy conversion efficiency limits. J. Appl. Phys. 92, 1329 (2002).

6. M.J. Keevers, M.J. Saris, G.C. Zhang, J. Zhao, M.A. Green. Screening of optical dopants in silicon solar cell for improved infrared response. In: Proceeding of the 13th European Photovoltaic Solar Energy Conf. (Nice, 1995).

7. M.J. Keevers, M.A. Green. Extended infrared response of silicon solar cells and the impurity photovoltaic effect. Solar Energy Materials and Solar Cells 41-42, 195 (1996).

8. M.J. Keevers, M.A. Green. Efficiency improvements of silicon solar cells by the impurity photovoltaic effect. Appl. Phys. Lett. 75, 4022 (1994).

9. Z.T. Kuznicki, M. Ley. New near-IR effect due to an amorphized substructure inserted in a c-Si solar-cell emitter. Solar Energy Materials and Solar Cell 72, 621 (2002).

10. M. Ley, Z.T. Kuznicki. Experimental and theoretical investigation of a new potential barriers due to sharp $\alpha$-Si-c-Si heterointerfaces buried in the solar cell emitter. Solar Energy Mater. and Solar Cell 72, 613 (2002).

11. Z.T. Kuznicki. Enhanced absorption and quantum efficiency in locally modified single-crystal Si. Appl. Phys. Lett. 81, 4853 (2003).

12. M. Ley, Z.T. Kuznicki, D. Ballutaude. Electronic transport in mind model solar cells: Collection efficiency in the presence of a-Si/c-Si heterointerfaces. In: Proceedings of the 29th Photovoltaic Specialists Conference (New Orlean, USA, 2002).

13. Ghania Azouzzi, Wahiba Tazibt. Improving silicon solar cell efficiency by using impurity photovoltaic effect. Energy Procedia 41, 40 (2013)

14. Zhao Baoxing, Zhou Jicheng, Chen Yongmin. Numerical simulation of the impurity photovoltaic effect in silicon solar cell doped with thallium. Physica B 405, 3834 (2010).

15. Akeed A. Pavel, M. Rezwan Khan, N.E. Islam. On the possibility to improve silicon solar efficiency through impurity photovoltaic effect and compensatio. Solid state electronic $\mathbf{5 4}, 1278$ (2010).

16. Ghania Azouzzi, Mohamed Cheegaar. Impurity photovoltaic effect in silicon solar cell doped with sulphur: A numerical simulation. Physica B 406, 1773 (2011).

17. E.T. Hu, G.Q. Yue, R.J. Zhang, Y.X. Cheng, L.Y. Chen, S.Y. Wang. Numerical simulation of multilevel impurity photovoltaic effect in sulfur doped crystalline silicon. Renewable Energy 77, 442 (2015).

18. S. Khelifia, J. Verschraegenb, M. Burgelmanb, A. Belghachia. Numerical simulation of the impurity photovoltaic effect in silicon solar cells. Renewable Energy 33, 293 (2008).

19. M. Schmeits, A.A. Mani. Impurity photovoltaic effect in c -Si solar cells. A numerical study. J. Appl. Phys. 85, 2207 (1999).

20. H. Kasai, T. Sato, H. Matsumura. Impurity photovoltaic effect in crystalline silicon solar cells. in: Proceedings of the 26th Photovoltaic Specialists Conference (Anaheim, 1997).

21. H. Kasai, H. Matsumura. Study for improvement of solar cell efficiency by impurity photovoltaic effect. Sol. Energy Mater. Sol. Cells 48, 93 (1997).

22. H. Matsumura, H. Kasai. Theoretical study for drastic improvements of solar cell. Jpn. J. Appl. Phys. 34, 2252 (1997).

23. H. Kasai, H. Matsumura. Optical absorption properties of indium-doped thin crystalline silicon films. Jpn. J. Appl. Phys. 37, 5609 (1998).

24. J.W. Mayer, L. Eriksson, J.A. Davids. Ion Implantation in Semiconductors (Academic Press, 1970).

25. R. Stangl, M. Kriegel, M. Schmidt. AFORS-HET, version 2.2,A numerical computer program for simulation of heterojunction solar cell and measurement. In: Proc. WCPEC-4, 4th World Conference on Photovoltaic Energy Conversion (USA, 2006).

26. S.M. Sze. Physics of Semiconductor Devices (Wiley, 1969).

27. S.J. Fornash, A. Rothwarf. Current Topics in Photovoltaics, Edited by T.J. Coutts, J. D. Meakin (Academic Press, 1985).

28. A.V. Kozinetz, V.A. Skryshevsky. Theoretical analysis of the efficiency of silicon solar cell with amorphized layer in space charge region. Ukr. J. Phys. 7, 620 (2015).

29. Z. Kuznicki, Meyreis Patrik. Methods for producing photovolaic material and device able to exploit high energy photons. US Patent 20110162700, July 7, 2011.

30. Z.T. Kuznicki. Process for the production of a photovoltaic material or device, material or device thus obtained and photocell comprising such a material or device. US Patent 5,935,345, August 10, 1999.

31. I.I. Ivanov, V.A. Skryshevsky, T. Nychyporuk, M. Lemiti, A.V. Makarov, N.I. Klyui, O.V. Tretyak. Porous silicon Bragg mirrors on single- and multi-crystalline silicon for solar cells. Renewable Energy 55, 79 (2013).

32. I.I. Ivanov, V.A. Skryshevsky, O.S. Kyslovets, T. Nychyporuk, M. Lemiti. Porous silicon Bragg reflectors on multicrystalline silicon wafer with $p-n$ junction. J. Phys.: Conf. Series 709, 012006 (2016).

33. S.V. Litvinenko, A.V. Kozinetz, V.A. Skryshevsky. Concept of photovoltaic transducer on a base of modified $p-n$ junction solar cell. Sensor and Actuators A: Physical 224, 30 (2015).

34. S. Khelifi, M. Burgelman, J. Verschraegen, Abderrahmane Belghachi. Impurity photovoltaic effect in GaAs solar cell with two deep impurity levels. In: Proc. of NUMOS Gent, 28-30 March, 2007 92, 1559 (2008). 
35. G. Beaucarme, A.S. Brown, M.J. Keevers, R. Corkish, M.A. Green. The impurity photovoltaic (IPV) effect in wide-bandgap semiconductors: an opportunity for veryhigh-efficiency solar cells? Progress in Photovoltaics 10, 345 (2002).

36. A.I. Manilov, S.V. Litvinenko, S.A. Alekseev, G.V. Kuznetsov, V.A. Skryshevsky. Use of powders and composites based on porous and crystalline silicon in the hydrogen power industry. Ukr. J. Phys. 55, 928 (2010).

37. V.G. Litovchenko, N.I. Klyui. Solar cells based on DLC film - Si structures for space application. Solar Energy Materials and Solar Cells 68, 55 (2001).

Received 25.09.17

О.В. Козинещъ, В.А. Скрищевсъкий

АМОРФІЗОВАНИЙ СУБМІКРОННИЙ

ШАР В ОБЛАСТІ ПРОСТОРОВОГО ЗАРЯДУ:

НОВИЙ ПІДХІД ДО ПРОБЛЕМИ

ПІДВИЩЕННЯ ЕФЕКТИВНОСТІ

КРЕМНІЕВИХ СОНЯЧНИХ ЕЛЕМЕНТІВ

Р е $з$ ю м е

Створення тонкого субмікронного аморфізованого шару (АШ) в області просторового заряду кремнієвого фотоперетворювача може збільшувати коефіцієнт корисної дії за рахунок домішкового фотоелектричного ефекту. Раніше цей підхід був застосований до структур з модифікованим ша- ром в області емітера. Такий шар можна створити за допомогою іонної імплантації. Вбудова шару в область просторового заряду є перспективним підходом, оскільки дозволяє досягти зменшення впливу рекомбінації (через енергетичні рівні в забороненій зоні та рівні, пов'язані із локальними станами інтерфейсів). Параметри фотоперетворення модифікованої структури досліджено методом чисельного моделювання, який дозволяє отримати світлові вольт-амперні характеристики для різних параметрів АШ. На підставі цих результатів визначено оптимальні параметри АШ. У такому випадку щільність струму короткого замикання збільшується завдяки поглинанню фотонів з енергією, меншою ніж ширина забороненої зони кремнію 1,12 eB, а напруга холостого ходу та фактор заповнення залишаються майже без змін. Теоретично, можливо отримати, підвищення ефективності на 1-2\% за абсолютною величиною. Це можливо, якщо шар з бар'єром у валентній зоні (менше, ніж 0,4 еВ) та бар'єром у зоні провідності (менше, ніж 0,1 еВ) створено у площині, яка відповідає близько 0,3 ширини області простору заряду. У іншому випадку деградація струму короткого замикання і фактора заповнення нівелює позитивний ефект додаткової фотогенерації. Збільшення напруги холостого ходу на $10-12 \%$ (внаслідок обмеження інжекції в $p$-базу) супроводжується суттєвою деградацією щільності струму короткого замикання. Так, для збільшення напруги холостого ходу шар із суттєвим потенціальним бар'єром в зоні провідності (близько 0,4 еВ) повинен бути розташованим поблизу базової області. 